\title{
Quality Infrastructure of India and Its Importance for Inclusive National Growth
}

\author{
D. K. Aswal* \\ CSIR-National Physical Laboratory, Dr. K. S. Krishnan Marg, New Delhi 110012, India \\ Received: 10 May 2020 / Accepted: 14 May 2020 / Published online: 30 May 2020 \\ (C) Metrology Society of India 2020
}

\begin{abstract}
In this feature article, the quality infrastructure (QI) of India is discussed. A national QI is comprised of internationally recognized metrology, standards and accreditation. The QI built on a technical hierarchy to ensure the accuracy and precision of measurements traceable to SI units, is basic enabling system for providing the conformity assessment (calibration and testing, certification and inspection). The QI is an invisible force that binds the four helices, namely government, university, S\&T institutions, civil society \& media and enterprises, which are responsible for the growth of economy and quality of life. The existing apex capabilities of National Physical Laboratory, India — the National Metrology Institute of the country, National Accreditation Board for Testing and Calibration Laboratories and the Bureau of Indian Standards, are described. The mechanisms of enhancing the individual capabilities of these QI institutions and to boost synergy amongst them are presented. The need of a robust QI facility by various stakeholders in the areas of implementation of regulations, industrial growth, international trade, food safety, environmental monitoring, sustainable energy, affordable health, attraction of foreign investments, etc. is highlighted.
\end{abstract}

Keywords: National quality infrastructure; Metrology; Accreditation; Standards; Conformity assessment

\section{Introduction of Quality Infrastructure}

For the year 2019, the International Monetary Fund (IMF) has listed India as the fifth largest economy of the world with gross domestic product (GDP) of $\$ 2.93$ trillion. USA (\$21.43 trillion), China ( $\$ 14.14$ trillion) Japan ( $\$ 5.15$ trillion) and Germany (\$3.86 trillion) are ahead of India [1]. India is aiming a goal of becoming a $\$ 5$ trillion economy by 2024 [2], which is a must to cater the livelihood of its large current population of 1.32 billion and that is expected to grow to 1.54 billion by 2035 [3]. This implies an exponential-like growth is needed for all the sectors contributing to the GDP, i.e. agriculture, service and industry. In addition, the export growth rate should be significantly high. Two recent books have aspiringly predicted that by harnessing technology and with a collaborative political, regulatory and business, the economy of India can surpass $\$ 20$ trillion by $2035-2040[4,5]$. It is well known that India is a country of magnificent paradoxes, and therefore, to enhance its economy and quality of

*Corresponding author, E-mail: dkaswal.npl@nic.in life, a synergy between the government and business, demographics and democracy, culture and modernity, traditional knowledge and modern Science \& Technology, etc. needs to be made stronger. Unfortunately, the end of December 2019 witnessed the beginning of the new coronavirus (nCov19) pandemic that has infected more than four million people and killed $>280,000$ worldwide till date (May 10, 2020). It is good news that $>1.44$ million people have also recovered [6]. The virus causing coronavirus-induced disease (COVID-19) is transmitted through droplets released during the exhales, coughs or sneezes of an infected person. To avoid the spread of pandemic, most of the governments across the world imposed a complete lockdown for month together [7]. This has resulted in halting all the economic activities worldwide, which has resulted in the loss of employment and prompted mass return of migrants to their native places [8]. This will pose a great difficulty in reviving the economy, and therefore, a new thinking will need to be evolved to achieve the set targets of the economy.

Quadruple helix $(\mathrm{QH})$ model of Carayannis and Campbell is widely used to understand how economies improve through the interactions amongst government, university/science \& technology ( $\& \& \mathrm{~T})$, industries and civil 
society \& media [9]. A schematic of QH model along with the responsibilities of each of the helices is depicted in Fig. 1. QH model essentially is an extension of triple helix (TH) model of Etzkowitz and Leydesdorff that deals with dynamics and evolution of university (S\&T)-industrygovernment relations and their impact on global economy and other challenges, including unemployment, low economic growth, healthcare needs, environment and uncoordinated regulatory systems [10-12]. The civil society and media were added in the $\mathrm{QH}$ model so that the innovation can effectively be communicated to the masses. In developed nations, the interactions amongst the four helices of QH are very strong and work in all directions, i.e. top down, bottom up, sideways and criss-cross. These strong interactions are facilitated through an invisible but robust quality infrastructure (QI), which ensures conformity assessment through well-established institutions of metrology, accreditation and standards. The QI in developed nations, e.g. USA, is well established and, therefore, has the strongest $\mathrm{S} \& \mathrm{~T}$ and industrial policies resulting in their high GDP [13].

United Nations Industrial Development Organization (UNIDO) has extensively been working to strengthen the industrial growth of developing nations [14-16]. UNIDO defines the QI as: "the system comprising the organizations (public and private) together with the policies, relevant legal and regulatory framework, and practices needed to support and enhance the quality, safety and environmental soundness of goods, services and processes. The quality infrastructure is required for the effective operation of domestic markets, and its international recognition is important to enable access to foreign markets. It is a critical element in promoting and sustaining economic development, as well as environmental and social wellbeing. It relies on metrology, standardization, accreditation, conformity assessment, and market surveillance". In a country, as depicted in Fig. 2. the quality infrastructure institutions, i.e. metrology, accreditation and standards, are usually formulated under national quality policy to ensure the QI services of conformity assessment through calibration, testing, certification and inspection.

Metrology is the science of measurement (physical, chemical and biological properties), embracing both experimental and theoretical determinations at any level of uncertainty in any field of science and technology [17]. Metrology is often classified into scientific metrology, industrial metrology and legal metrology. Scientific metrology deals with research and development of new measurement standards as well as their maintenance and dissemination. This is performed by National Metrology Institutes (NMI) of the country. Industrial metrology deals with the application of metrology to industrial processes and ensures the correctness of measurement instruments through their calibration. Precise and accurate measurements improve the quality of the product and, therefore, their market. The strength of industrial metrology, therefore, governs the economic and industrial development of a country. Legal Metrology deals with the statutory requirements concerning measurements as well as the law enforcement on measurements. These statutory requirements arise from a need for the protection of public health and safety, consumers rights, enabling taxation, the environment, and fair trade are performed by competent bodies. Accreditation is a process by which an authorized body officially recognizes (i.e. third-party attestation) that the person or organization is competent to carry out specific
Fig. 1 Well-functioned quadruple helix $(\mathrm{QH})$ comprising governmentuniversity/S\&T institutesindustry-civil society \& media is needed to achieve a high economy and high quality of life. A robust quality infrastructure (QI) is essential for facilitating the strong interactions amongst the helices of $\mathrm{QH}$

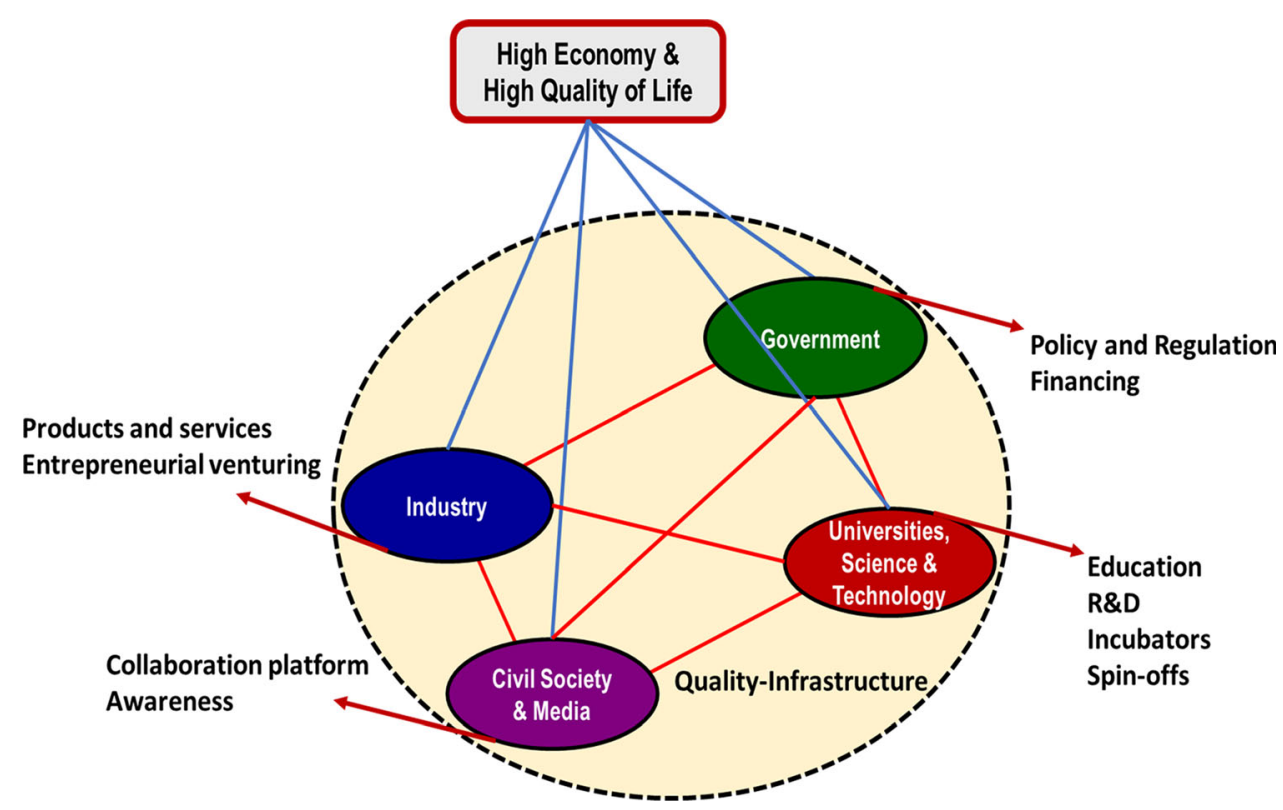




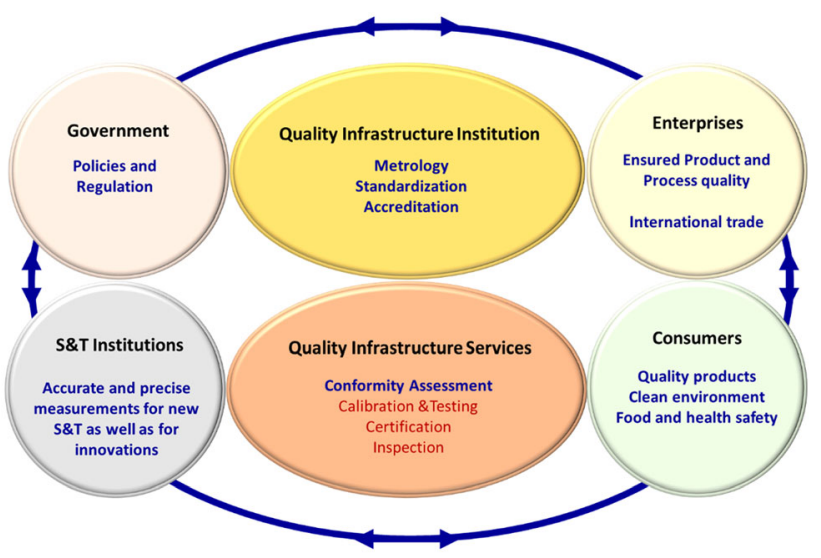

Fig. 2 Strong Quality Infrastructure (QI) institutions in a country are essential for the conformity assessment of international level to support government policies and regulations, for innovation in the S\&T institutions through precise and accurate measurements, for industries to produce internationally competitive high-quality products and their international trade, and high-quality of life for common citizens

tasks with a level of internationally accepted competence. Standardization involves development of technical standards and their implementation to ensure the quality, compatibility, interoperability and safety. Therefore, QI is the basic enabling system of a nation for providing the conformity assessment (compliance with standards and technical regulations) of products and processes with international acceptance through calibration and testing (the determination of the characteristics of a product), certification (a formal and written confirmation that a product, service, organization, system or individual complies with a given set of specifications and/or standards) and inspection (the determination whether products meet the requirements of a given standard) [18].

QI in nutshell is a complete package for all-round growth of a nation as it: (1) contributes to the formulation of government policies and regulations for $\mathrm{S} \& \mathrm{~T}$, industrial development and competitive international trade; (2) supports enterprises for production of international competitive products and apprises them new trade standards; (3) assists S\&T institutions for scientific discoveries and innovation through accurate and precise measurements; and (4) addresses the needs of the consumers in terms of quality products and services at par with international standards, food and health safety, environment and climate change, and efficient use of natural and human resources. The QI also acts a foundation for achieving the sustainable development goals, envisaged by UN to ensure the inclusive economic growth and prosperity, dignified livings of people and the protection of the earth. The International Network of Quality Infrastructure (INetQI) [19]—a consortium of twelve international organizations-promotes the significances of QI and its effective global implementation, particularly in developing nations with ensured metrological traceability to SI units. These twelve international organizations include International Bureau of Weights and Measures (BIPM), International Accreditation Forum (IAF), International Electrotechnical Commission (IEC), International Laboratory Accreditation Forum (ILAC), International Standards Organization (ISO), International Trade Centre (ITC), International Telecommunication Union (ITU), International Organizations of Legal Metrology (OIML), United Nations Economic Cooperation for Europe (UNECE), World Bank Group (WBG), World Trade Organization (WTO) and UNIDO.

\section{India's Quality Infrastructure and Its International Recognition}

Figure 3 summarizes the international QI organizations along with the QI institutions of India and a comparison with that of USA - one of the best QI in the world. India has the desired QI system, and all of its three components, namely metrology, accreditation and standards, have wellestablished international affiliations. However, despite international affiliations, the QI strength of different countries can be widely dissimilar. The strength of QI system of a nation mainly depends upon (1) overall measurable capabilities of international equivalence available with apex QI institutions and (2) the dissemination mechanism of the available QI capabilities to all the stakeholders across the country. In USA, as shown in Fig. 3, the National Institute of Standard and Technology (NIST) has multiple responsibilities, i.e. scientific metrology, Legal metrology (ILMG/NIST), accreditation (NVLAP/NIST) and standards [20]. Multiple roles of NIST's for measurements, standards and legal metrology allow them to ensure measurement traceability for quality assurance as well as in harmonizing the documentary standards and regulatory notifications. For accreditation and standards, USA has multiple organizations (as listed in Fig. 3). On the other hand, the components of India's QI system belong to independent organizations. The metrology is looked after by National Physical Laboratory of India (NPLI) [21] with Bhabha Atomic Research Centre (BARC) as the designated Institute for the ionization radiation [22], legal metrology comes under Ministry of Consumer Affairs [23], accreditation is the responsibility of Quality Council of India (QCI) [24] having five independent boards, namely NABCB, NABET, NBQP, NABH and NABL, and Bureau of Indian Standards (BIS) [25] is the body for Indian standards. 


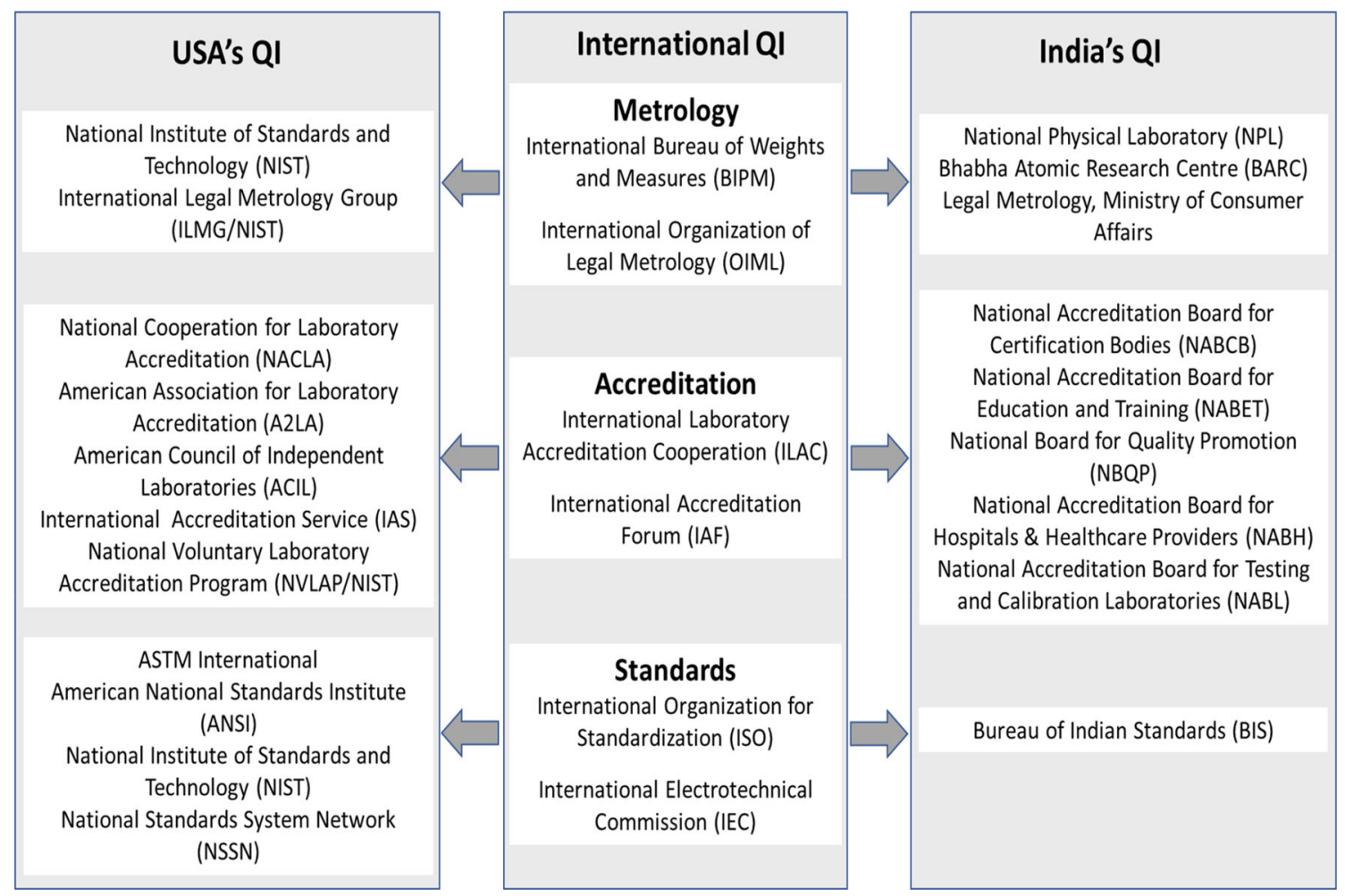

Fig. 3 Components of international quality infrastructure and corresponding QIs of USA and India

\subsection{Metrology in India}

The NPLI is the NMI of the country since 1956 formed by an Act of Parliament, Legal Metrology, Government of India. NPLI deals with all the seven basic SI units and their derivates, except the ionization radiation for which Bhabha Atomic Research Centre (BARC), Mumbai, was made designated institute (DI) in 2003. NPLI is a member of BIPM, signatory of International Committee of Weights and Measures-Mutual Recognition Agreement (CIPM MRA) [26] and founding member of the Asia Pacific Metrology Program (APMP) [27]—one of the six Regional Metrology Organizations (RMO). The key roles of BIPM and RMOs are to homogenize the accurate and precise measurement capabilities across the world through NMIs. The Joint Committee of the Regional Metrology Organizations and the BIPM (JCRB CIPM) analyse the calibration and measurement capabilities (CMCs) of NMIs and place the information in the website of Key Comparison Database of BIPM (KCDB-BIPM) [28]. CMCs are the highest level of calibration and measurements, guaranteed by an institute to customers of its metrological services, in the form of the value of expanded uncertainty of measurement results.

Under the CIPM MRA, NPLI has adopted working quality management (QM) system according to ISO/IEC 17025 as well as ISO 17034 for certified reference material.
NPLI like any other NMI of the world has three major tasks: (1) To contribute in the definition of internationally accepted units of measurements. (2) The realization of primary/national measurement standards using well-established procedures of CMCs. (3) To provide measurement traceability through either calibration and/or certified reference materials to all the stakeholders in the country. These responsibilities of NPLI have been depicted using a 3D pyramid installed in the NPLI campus, see Fig. 4. The NPLI has voted for the redefinition of SI units based on the fundamental constants in the 26th CGPM held in France in 2018 and got it implemented in India on World Metrology Day on 20 May $2019[29,30]$. As can be seen from the KCDB-BIPM, NPL, India has $236 \mathrm{CMCs}$ which is much lower as compared to $1889 \mathrm{CMCs}$ of NIST, USA. Tables 1 and 2 summarize the $236 \mathrm{CMCs}$ and $130 \mathrm{key} / \mathrm{supplemen-}$ tary comparisons of NPL-India that covers several metrology areas related to physico-mechanical, electrical and electronics, time and frequency, chemistry, etc. In addition, the BARC has $52 \mathrm{key} / \mathrm{supplementary}$ comparisons, as listed in Table 3, in the area of ionization radiation. The interlaboratory comparisons are prerequisite for the declaration of CMCs. A large number of CMCs indicate that the NMI has participated in technologically complex interlaboratory comparisons and, therefore, has measurement capabilities in wide range of science and technology that facilitates their fundamental science and 


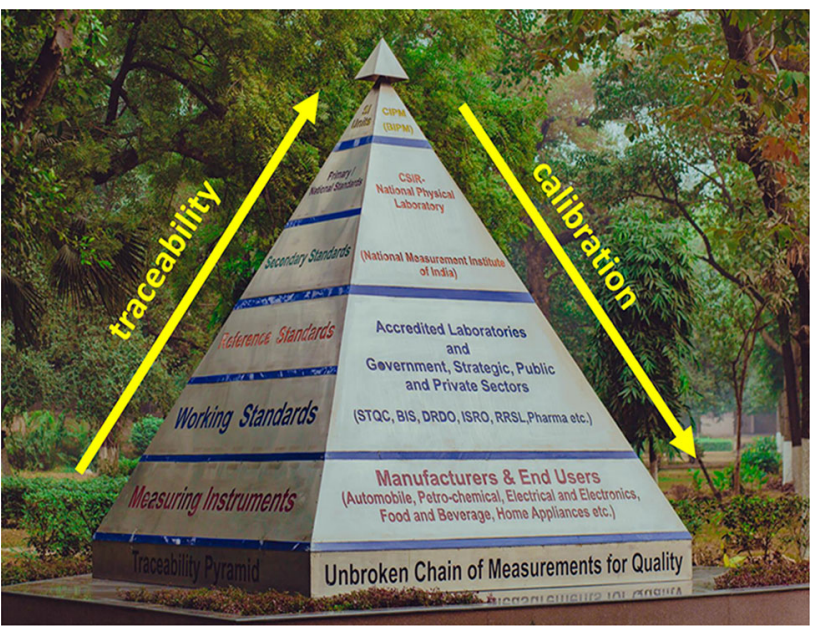

Fig. 4 Photograph of a 3-dimensional model of metrology traceability pyramid at the NPLI campus showing the unbroken chain of measurements traceable to the SI units and the responsible organizations in India for dissemination of metrology traceability to manufacturers and end users (The pyramid was installed in 2016 based on the concepts of Dr. D. K. Aswal and Dr. V.N. Ojha)

Table 1 CMCs of NPL-India at KCDB-BIPM [28]

\begin{tabular}{|c|c|c|c|}
\hline Metrology area & $\begin{array}{l}\text { Number } \\
\text { of CMCs }\end{array}$ & Metrology area & $\begin{array}{l}\text { Number } \\
\text { of CMCs }\end{array}$ \\
\hline $\begin{array}{l}\text { AC current and } \\
\text { power }\end{array}$ & 21 & Photometry & 10 \\
\hline $\begin{array}{l}\text { DC voltage, } \\
\text { current and } \\
\text { resistance }\end{array}$ & 22 & Pressure & 17 \\
\hline Density & 02 & $\begin{array}{l}\text { Properties of } \\
\text { detectors and } \\
\text { sources }\end{array}$ & 04 \\
\hline $\begin{array}{r}\text { Dimensional } \\
\text { metrology }\end{array}$ & 42 & $\begin{array}{l}\text { Radiofrequency } \\
\text { measurements }\end{array}$ & 11 \\
\hline Fluid flow & 03 & Sound in air & 23 \\
\hline Force & 06 & Temperature & 04 \\
\hline Frequency & 08 & Time interval & 01 \\
\hline $\begin{array}{l}\text { High frequency } \\
\text { and current }\end{array}$ & 13 & Time scale difference & 02 \\
\hline $\begin{array}{l}\text { Impedance up to } \\
\mathrm{MHz} \text { frequency }\end{array}$ & 07 & $\begin{array}{l}\text { Torque, viscosity, } \\
\text { hardness and } \\
\text { gravity }\end{array}$ & 10 \\
\hline Laser frequency & 02 & Vibration & 11 \\
\hline Mass standards & 16 & Ozone & 01 \\
\hline
\end{tabular}

creates new technology and innovations, which in turn contributes to their economy and quality of life. Therefore, there is a need for both NPL and BARC to enhance their CMCs at the KCDB.

In 2017, NPLI has launched certified reference materials under the trademarked as Bhartiya Nirdeshak Dravya, BND $^{\circledR}$ [21]. So far 72 BNDs have been launched related to
Table 2 Key and supplementary comparisons of NPL-India at KCDB-BIPM [28]

\begin{tabular}{llll}
\hline Metrology area & Number & Metrology area & Number \\
\hline $\begin{array}{l}\text { Mass and related } \\
\text { quantities }\end{array}$ & 39 & $\begin{array}{c}\text { Chemical and } \\
\text { biology }\end{array}$ & 18 \\
$\begin{array}{c}\text { Electricity and } \\
\text { magnetism }\end{array}$ & 30 & Thermometry & 08 \\
$\begin{array}{l}\text { Length } \\
\begin{array}{c}\text { Acoustic, ultrasound and } \\
\text { vibration }\end{array}\end{array}$ & 11 & $\begin{array}{c}\text { Photometry and } \\
\text { radiometry }\end{array}$ & 03 \\
\hline
\end{tabular}

Table 3 Key and supplementary comparisons of BARC at KCDBBIPM [28]

\begin{tabular}{ll}
\hline Metrology area & Number \\
\hline Measurement of radionuclides & 41 \\
X- and gamma radiation & 07 \\
Neutron measurement & 04 \\
\hline
\end{tabular}

high purity gold, coal, cement, water, hardness, petroleum products, etc. The indigenous development of BNDs has greatly benefited the relevant Indian industries in terms of ease of availability, low cost and savings of foreign exchange. NPL is a member of COMAR (Code d'Indexation des Matériaux de Référence) database [31], and therefore, the information on BNDs is also uploaded on COMAR database for the international community. As CRMs/BNDs are the standards used to ensure quality and metrological traceability of products, to validate analytical measurement methods, or for the calibration of instruments, NPL needs to develop BNDs belonging to several fields, such as food, edible oils, minerals, heavy metals, pesticides, pharmaceuticals and textiles to ensure the quality and safety of the products.

The benefits of the metrology need to be transferred to the common citizen of a country, and this is often done by Legal metrology through appropriate law enforcement. The legal metrology ensures fair trade, specifically in the area of weights and measures, and has a main objective to assure citizens of correct measurements. The responsibilities of legal metrology system include (1) Type approval of measuring equipment, (2) Calibration and verification of measuring equipment, (3) Market surveillance of measuring equipment falling within the scope of regulation and (4) Controls of pre-packaged goods. Therefore, legal metrology is an integral part of technical regulation regime and has to comply with the requirements of Agreement on Technical Barriers to Trade (TBT Agreement) of World Trade Organization (WTO). In addition, legal metrology is needed for technical regulations to protect the health and 
safety of individuals, and the environment. In India, the legal metrology system is dealt by the Directorate of Legal Metrology, Department of Consumer Affairs, Government of India. Directorate of Legal Metrology is a member of International Organization of Legal Metrology (OIML) [32] and has adopted metric system and the International System of Units in the country. The Legal Metrology (National Standards) Rules, 2011, prescribe the standards of weights and measures, which are administered by the state governments. The Legal Metrology Act 2009 specifies the roles and responsibilities of Central and State Governments [33]. The Central Government deals with matters related to implementation of OIML recommendations, formulation of national policy and laws on weights and measures, technical regulations, training and setting up of precision laboratory. State and union territory governments have the responsibilities for the enforcement of the laws framed by the central government through their offices of the Controller of Legal Metrology (Weights \& Measures). The legal metrology has a network of laboratories for weights and measures: five regional reference standard laboratories (RRSL) located at Ahmedabad, Bangalore, Bhubaneswar, Faridabad and Guwahati, which are set up by central government and all of them take measurement traceability from NPL, state-level secondary standards laboratories and district-level working standards laboratories. The nationwide network of the legal metrology laboratories is responsible for the calibration and testing of equipment of weights and measures, ensuring the measurement traceability to secondary standards, and awareness programmes for the consumers. Recently, LM has started a nationwide programme on dissemination of Indian Standard Time, traceable to NPLI, through its RRSLs. The dissemination IST traceable to NPLI will help the country in the field of cybersecurity, power sector, telecom sector, digital, aviation, etc.

\subsection{Standardization in India}

Internationally, the standards are known to offer economic benefits to industries in the following ways: (1) optimization of the internal operations of the industry that may result in reduction in operational time, increase in productivity, decrease in waste and reduction in procurement costs, (2) innovation in new processes and products as well as scaling up operations/manufacturing, (3) identification of new domestic and export markets. Therefore, standards not only assist in improving the quality of products in the country but also help in exporting them. In India, the Bureau of Indian Standards (BIS), working under the aegis of Ministry of Consumer Affairs, Food \& Public Distribution, Government of India, is the standardization body [25]. BIS has the authority to exclusively publish the Indian Standards (IS). BIS is a member of several international organizations, i.e. International Organization for Standardization (ISO), International Electrotechnical Commission (IEC), Pacific Area Standards Congress (PASC) and South Asian Regional Standards Organisation (SARSO). As shown in Table 4, BIS develops IS through its 16 Division Councils having 344 Technical Committees, and many of them act as mirror committees at ISO and IEC. So far, BIS has developed $>20,000$ standards in the diverse

Table 4 List of the Division Councils of the Bureau of Indian Standards (BIS) responsible for development of Indian Standards [25]

\begin{tabular}{|c|c|c|c|}
\hline S. no & Technical division & Technical committees & Published standards \\
\hline 1 & Civil engineering department (CED) & 36 & 1806 \\
\hline 2 & Chemical department (CHD) & 25 & 1819 \\
\hline 3 & Electrotechnical department (ETD) & 44 & 1707 \\
\hline 4 & Food and agriculture department (FAD) & 26 & 2081 \\
\hline 5 & Electronics and information technology department (LTD) & 32 & 1738 \\
\hline 6 & Mechanical engineering department (MED) & 28 & 1341 \\
\hline 7 & Medical equipment and hospital planning department (MHD) & 20 & 1348 \\
\hline 8 & Management and systems department (MSD) & 12 & 420 \\
\hline 9 & Metallurgical engineering department (MTD) & 20 & 1656 \\
\hline 10 & Petroleum, coal and related products department (PCD) & 15 & 1445 \\
\hline 11 & Production and general engineering department (PGD) & 24 & 2446 \\
\hline 12 & Service sector department-I (SSD-I) & 1 & 0 \\
\hline 13 & Service sector department-II (SSD-II) & 0 & 0 \\
\hline 14 & Transport engineering department (TED) & 18 & 1153 \\
\hline 15 & Textile department (TXD) & 26 & 1309 \\
\hline 16 & Water resources department (WRD) & 17 & 449 \\
\hline Total & & 344 & 20718 \\
\hline
\end{tabular}


areas of manufacturing and service sectors. These technical standards are used to ensure desirable characteristics of products and services, including quality, safety, reliability, efficiency, environmental friendliness and interchangeability. The BIS also has several schemes of ensuring the conformity assessment including ISI certification for the certification of goods and articles, self-declaration scheme of conformity, hallmarking of gold jewellery and Foreign Manufacturers' Certification Scheme (FMCS). Thus, adoption of the IS standards and conformity assessment schemes have significantly contributed to the industrial growth in the country. International standards are often adopted in case IS are not available. The most adopted ISO standards include: (1) Quality Management Systems (ISO 9001), (2) General requirements for the competence of testing and calibration laboratories (ISO/IEC 17025:2017), (3) Environmental Management Systems (ISO 14001), (4) Conformity assessment-General requirements for proficiency testing (ISO/IEC 17043:2010), (5) General requirements for the competence of reference material producers (ISO 17034:2016), (6) Information security management systems (ISO/IEC 27001:2005) and (7) Risk Management (ISO 31000:2009).

Though BIS is the standard body of India but several other ministries and departments develop standards for their area of specializations, usually referred as standard development organization (SDO), and few of these standards are adopted also by the BIS. These SDO's are:

1. Agricultural \& Processed food Products Export Development Authority (APEDA) [34]: An autonomous body under Department of Commerce for the development of standards and specifications for the exports of agriculture and food products.

2. Automotive Research Association of India (ARAI) [35]: An organization under Ministry of Heavy Industries \& Public Enterprises for the standard formulations and certification of vehicles, type approval

3. Building Materials \& Technology Promotion Council (BMTPC) [36]: An autonomous body under Ministry of Housing \& Urban Affairs for the formulation of standards development for innovative and emerging building materials and technologies.

4. Bureau of Energy Efficiency (BEE) [37]: An autonomous body under the Ministry of Power for the formulation of energy efficiency standards for appliances

5. Directorate of Marketing and inspection (DMI) [38]: under Ministry of Agriculture \& Farmers Welfare for the standardization, grading and quality control of agricultural and allied produce. AGMARK certification scheme is popular for domestic trade and export.
6. The Food Safety and Standards Authority of India (FSSAI) [39]: under the Indian Ministry of Health \& Family Welfare (MoHFW) develops standards for food safety. FSSAI represents India in Food and Agriculture Organization of the United Nations (FAO) and the World Health Organization (WHO).

7. Indian Roads Congress (IRC) [40]: Affiliated to Ministry of Road Transport and Highways for the development of standards for roads and highways planning and construction.

8. Ministry of AYUSH (Ayurveda, Yoga \& naturopathy, Unani, Siddha and Homoeopathy) [41]: develops standards for pharmacopoeia and homoeopathy drugs

9. Quality Council of India (QCI) [24]: NABH develops standards for hospital accreditation and NABET develops standards for school accreditation.

10. Standardization Testing and Quality Certification (STQC) [42]: an organization under Ministry of Electronics \& Information Technology (MeiTY) for quality assurance and conformity assessment in electronics, information security and software testing/certification.

11. Telecommunication Engineering Centre (TEC) [43]: under Department of Telecommunications (DOT) develops standards for telecom equipment and interoperability.

12. Telecommunications Standards Development Society, India (TSDSI) [44]: a society under Department of Telecommunications develops standards for telecommunication.

\subsection{Accreditation in India}

In India, the National Accreditation Board for Testing and Calibration Laboratories (NABL) [45] undertakes the assessment and accreditation of Testing and Calibration Laboratories, in accordance with the international standard ISO/IEC 17025 and ISO 15189. NABL is a signatory of Mutual Recognition Arrangement (MRA) of International Laboratory Accreditation Co-operation (ILAC) [46] and Asia Pacific Laboratory Accreditation Co-operation (APLAC) [47]. NABL does accreditation of conformity assessment bodies (CAB) including calibration and testing laboratories (ISO10025), proficiency testing provider (PTP) using ISO 17043 and reference material producers (RMP) using ISO 17034. The accreditation process has a responsibility to ensure that the $\mathrm{CAB}$ meets metrological traceability to SI units through the primary/national measurement standards of the NMI, as depicted in Fig. 4. Thus, NABL accreditation of testing laboratories produces test results of internationally acceptable level of competence. 
Table 5 Accreditations granted by the NABL until 31.3.2020 [45]

\begin{tabular}{llc}
\hline NABL Scheme & $\begin{array}{l}\text { Accreditation } \\
\text { standard }\end{array}$ & $\begin{array}{l}\text { Accreditations } \\
\text { granted }\end{array}$ \\
\hline Calibration laboratories & ISO 17025 & 970 \\
Testing laboratories & ISO 17025 & 3414 \\
$\begin{array}{l}\text { Medical laboratories } \\
\begin{array}{l}\text { Proficiency testing } \\
\text { providers }\end{array}\end{array}$ & ISO 15189 & 1206 \\
$\begin{array}{l}\text { Reference material } \\
\text { producers }\end{array}$ & ISO 17034 & 43 \\
\hline
\end{tabular}

As shown in Table 5, NABL so far has granted $>5600$ accreditations to calibration laboratories, testing laboratories, medical laboratories, proficiency testing provider and reference material producers. The scope of NABL accreditation is (1) Calibration laboratories: electrotechnical, mechanical, fluid flow, thermal, optical, radiological and medical devices; (2) Testing laboratories: biological, chemical, electrical, electronics, fluid flow, mechanical, non-destructive testing (NDT), photometry, radiological, forensic, diagnostic radiology QA testing and software \& IT system; (3) Medical laboratories: clinical biochemistry, clinical pathology, haematology \& immunohematology, microbiology \& infectious disease serology, histopathology, cytopathology, flow cytometry, genetics, nuclear medicine (in vitro tests only); (4) Reference material producers: chemical composition, biological \& clinical properties, physical properties, engineering properties and miscellaneous properties. During the period of COVID pandemic, NABL has accredited 142 medical testing laboratories across the country for RT-PCR RNA Virus/ COVID-19, which has greatly benefited the country in terms of conducting these very important tests.

NABL accreditation has advantage in terms of enhance business as major government ministries and regulators (e.g. BIS, legal metrology, Directorate General for Foreign Trade, Ministry of Drinking Water and Sanitation, Ministry of Health \& Family Welfare, Food Safety and Standards Authority of India, etc.) have mandated NABL accreditation for all laboratories performing conformity assessment for their schemes. Similarly, for RMPs, the NABL accreditation has an advantage that they obtain metrological traceability from the NPL and, therefore, can produce and market their certified reference materials under the $\mathrm{BND}^{\circledR}$, which are reached to international community through COMAR database.

The accreditation of $\mathrm{CABs}$ not requiring the metrology traceability is conducted by other boards of QCI, namely National Accreditation Board for Certification Bodies (NABCB) [48], National Accreditation Board for Hospitals and Healthcare Providers (NABH) [49] and National Accreditation Board for Education \& Training (NABET) [50]. The NABCB operates under the framework of ISO 17011 and accredits CABs for inspection bodies (e.g. BIS for product certification), management systems for food safety, medical devices, environmental monitoring, health safety, occupational hazards, information security, energy, etc. Other boards, namely NABET for the management of education and training and $\mathrm{NABH}$ for the management of hospitals, function under self-regulation.

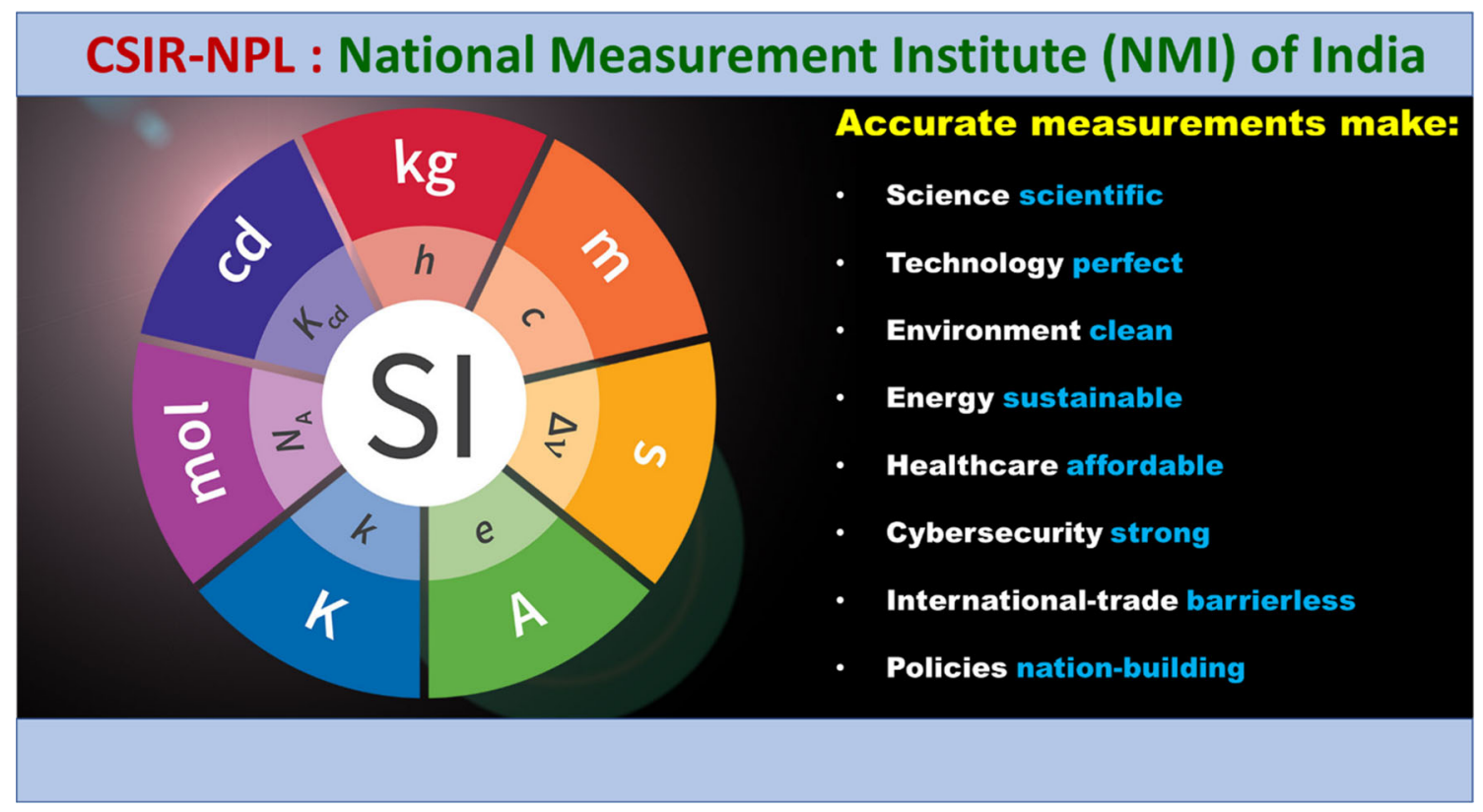

Fig. 5 "Graffiti Wall" painted at NPL campus to mark the worldwide implementation of redefinition of SI units based on the fundamental constants on May 20, 2019, and the implication of accurate measurements traceable to SI units (Conceptualized by Dr. D.K. Aswal) 
Table 6 A partial list of authorities in India related to regulatory, policies, science and technology, forensic, strategic sectors etc

\begin{tabular}{|c|c|}
\hline Category & Authority \\
\hline Academia and $\mathrm{S} \& \mathrm{~T}$ & $\begin{array}{l}\text { University Grant Commission (UGC) } \\
\text { Ministry of Science and Technology (MoST) }\end{array}$ \\
\hline Agricultural and Processed Food Products & Agricultural and Processed Food Products Export Development Authority (APEDA) \\
\hline Digital signatures & Controller of Certifying Authorities (CCA) \\
\hline Drugs and medical devices & Drugs Controller General of India (DGCI) \\
\hline Electronics and IT & Standardization Testing and Quality Certification (STQC) \\
\hline Energy efficiency & Bureau of Energy Efficiency (BEE) \\
\hline Environmental pollution & Central Pollution Control Board (CPCB) \\
\hline Export certification & Export Inspection Council (EIC) \\
\hline Food Safety & Food Safety and Standards Authority of India (FSSAI) \\
\hline Forensic & Central Forensic Science Laboratory (CFSL) \\
\hline Industrial policy & Department of Industrial Policy and Promotion (DIPP) \\
\hline Petroleum products & Petroleum \& Natural Gas Regulatory Board (PNGRB) \\
\hline Radiation safety & Atomic Energy Regulatory Board (AERB) \\
\hline Renewable energy & Ministry of New and Renewable Energy (MNRE) \\
\hline Securities market & Securities and Exchange Board of India (SEBI) \\
\hline Strategic sectors & $\begin{array}{l}\text { Department of Atomic Energy (DAE), } \\
\text { Indian Space Research Organization (ISRO) } \\
\text { Defence Research and Development Organization (DRDO) }\end{array}$ \\
\hline Telcom regulatory & Telcom Regulatory Authority of India (TRAI) \\
\hline Weights and measures & Legal Metrology \\
\hline
\end{tabular}

All of them need conformity assessment to meet their targets

\section{Quality Infrastructure for India's Comprehensive Growth}

Figure 5 shows the photograph of the "graffiti wall" at NPL campus that was painted on 20 May 2019 to mark the worldwide implementation of redefinition of SI units based on the fundamental constants. It is evident that the accurate measurements that get implemented though rigorous conformity assessment contribute to the overall growth of the country through discoveries and innovations in the areas of science, development of high end technologies, sustainable green energy, environment free from pollution, affordable healthcare system, enhanced international trade, strong cybersecurity, and formulation regulation and policies that benefits the country. Conformity assessment ensures manufacturers that their products and services are in accordance with the desired specifications of national/ international standards, ensuring quality, reliability, efficiency, safety, effectiveness, interoperability and environmental sustainability. A certification mark based on conformity assessment provides consumer a confidence that he/she has got the products or services of the desired specification. Such products can be exported without facing any hurdle to technical barrier to trade.

Table 6 summarizes a partial list of authorities of Government of India related to regulators, policies, science and technology, forensic, strategic sectors, etc. All of them need conformity assessments to meet their targets. The regulators demand mandatory conformity assessment in the regulation that allows them to enforce legislation pertaining to national health, safety, food, radiation safety, finance, energy, environment, etc. The regulators, through appropriate legal and regulatory notifications in their domain, ensure that the interests of the public are protected. In order to implement and enforce their regulations, they require the conformity assessment of technical, safety and quality standards. For example, the Central Pollution Control Board (CPCB) has the major responsibility of prevention, control or abatement of water and air pollution across the country. To implement these, $\mathrm{CPCB}$ requires a robust quality infrastructure to ensure that the measured data on air and water pollutions are trustworthy. Currently, the air quality and emission monitoring equipment in the country are calibrated and certified by foreign certifying agencies as the country did not have any certification agencies having the primary measurement standards. Recently, the Government of India has Gazette Notified the NPL as the certifying agency for the air quality and industrial emission monitoring equipment in the country as per the Indian standards, which not only will bring down the costs but also improve the measurement accuracies. It is very essential for the regulators to be aware of the 
metrological capabilities of NPL in their respective area of technical confirmatory assessments, otherwise the possibility of introducing unnecessary regulations or technical requirements may exist, which can become difficult to comply. In addition, if the regulations are substantially different to those of other countries, then they can lead to technical barriers to trade. Therefore, robust conformity assessment services, harmonized internationally, are essential for facilitation of smooth import/export services. Poor conformity assessment services can allow entry of the imports which are substandard and toxic in nature. One can find several news reports stating the import of poor quality [51-56], e.g. steel, toys, tyres, light emitting diodes (LEDs), electronic items, solar panels, food items, etc. Similarly, inferior conformity assessments procedures can lead to technical barriers to trade, causing hurdles to the cross-border trade. The exporters are asked for multiple testing and/or certification of products, and in many cases, the products are rejected at the border causing them a huge monitory loss. There are several cases of the rejection of Indian export at the border of foreign country due to not meeting the standards [57-59]. In both the cases, i.e. import of poor-quality products and rejection of Indian exports, the nation undergoes a huge economic loss. In the case of poor-quality imports having toxicity, not only their disposal becomes economic burden but also are the sources for health hazards.

A strong quality infrastructure is also needed for the strengthening of Micro, Small and Medium Enterprises (MSME) [60] sector as well as the Make in India programme initiated by Department of Industrial Policy and Promotion (DIPP) [61]. MSMEs are spread across the country and produce a range of products that cater the needs of local as well as global market. According to a 2013 report, MSME contributed $8 \%$ of the GDP, created $45 \%$ of the manufacturing output and contributed to the $40 \%$ of the exports [62]. In addition, MSMEs provide large employment opportunities (second after the agriculture sector) and act as the nucleation for entrepreneurship and innovation. However, it has been observed that contributions of MSMEs are declining gradually in GDP, manufacturing output and exports. The difficulties of MSMEs have further escalated by the outbreak of the COVID-19 pandemic as the nation went for a complete lockdown for months together. After the relaxation in the lockdown, majority of the workers migrated to their native villages, and this would create acute manpower shortage to the MSMEs. Therefore, to revive the MSMEs in coming days, new government policies should be formulated in which the concept of quality infrastructure must be built to ensure the production of internationally competitive products. Moreover, the success of Make in India, which is an excellent programme that encourages foreign companies to manufacture their products in India and aims at creating new job opportunities, requires an established quality infrastructure at par with international standard. A strong QI assists in the attraction of foreign investment as it allows innovation for the development products (e.g. analytical instruments, medical, defence, aerospace, etc.) compatible to Indian environmental conditions as well as their conformity assessment as per the national/international standards.

\section{Concluding Remarks}

All the three pillars of quality infrastructure (i.e. metrology, standards and accreditation) are well placed in India. However, the strengthening of quality infrastructure would require (1) enhancing the apex capabilities by NPL/BARC/ LM, all the boards under QCI (including NABL) and BIS, and (2) a better synergy amongst these three pillars. The synergized QI should establish a collaboration with four helices (government, university/S\&T institutions, civil society \& media and enterprises), for enhancing the growth of economy and quality of life. To strengthen the quality infrastructure of the country, the following suggestions are made.

1. The calibration and measurement capabilities (CMCs) of NPL reported at KCDB of BIPM need to be expanded for the areas belonging to energy, environment monitoring, biomedical, quantum standards, Indian Standard Time (IST), etc. Of course, the setting of new primary/national standards requires high capital investment, trained manpower and international intercomparison. NPL has taken up setting up of primary standards in the areas of air quality and emission monitoring as well as in the solar cell efficiency. It is creditable that NPL has trademarked the certified reference materials as Bhartiya Nirdeshak Dravya $\left(\mathrm{BND}^{\circledR}\right)$ and has already developed a national mechanism for the production of BNDs in collaboration with Indian industries producing the reference materials in the fields of petroleum, cement, water, soil, metals and minerals, food, etc. These BNDs are essential to support several thousands of laboratories across the country for generating the accurate and reliable test results.

2. NABL has accredited $>5600$ laboratories in different fields but has a long way to go as several thousands of the laboratories still need to be accredited. In order to ensure the metrological traceability to SI units, the NABL should categorize calibration laboratories into two tiers. The Tier 1 calibration laboratories (equivalent to those of regional reference laboratories of 
Legal Metrology) get the measurement traceability directly from the NPL and, therefore, will have lower measurement uncertainty. Tier 1 status can be assigned to laboratories under different ministries and/or private laboratories having the desired infrastructure and assessed by NPL. The Tier 2 calibration laboratories would get the measurement traceability from Tier 1 and disseminate them to testing laboratories across the country.

3. BIS should also develop new Indian Standards that benefit the MSMEs. Moreover, testing laboratories used for conformity assessment should ensure the measurement traceability to the SI units.

To sum up, a strong QI is essential for the "Made in India" programme that becomes almost essential for the nation in view of the COVID pandemic, whereby the fundamental shifts in the national policies are expected. To revive the national economy and creation of employment, MSMEs need to be encouraged for the development of products as per the international standards by ensuring that they utilize the existing quality infrastructure of the country.

\section{References}

[1] World Economic Outlook Database, October 2019". IMF.org. International Monetary, 2019. Retrieved from https://www.imf. org/external/pubs/ft/weo/2019/02/weodata/index.aspx.

[2] From fifth-largest to \$5-trillion economy, 2020, Retrieved from https://economictimes.indiatimes.com/blogs/et-editorials/fromfifth-largest-to-5-trillion-economy/.

[3] Population of India, 2020, Retrieved from https://www. livepopulation.com/country/india.html.

[4] J. Bharat, Navigating India: \$18 Trillion Opportunity. Rupa Publisher, Kolkata, 2017

[5] S. Kumar, India: A 20 Trillion Economy by 2035-2040?. Adhyyan Books, 2018.

[6] Rolling updates on coronavirus disease (COVID-19), World Health Organization, https://www.who.int/emergencies/ diseases/novel-coronavirus-2019/events-as-they-happen.

[7] Coronavirus India lockdown Day 41 live updates, The Hindu, May 4, 2020. Retrieved from https://www.thehindu.com/news/ national/india-coronavirus-lockdown-may-4-2020-live-updates/ article31497930.ece.

[8] Coronavirus: Lockdown in India has affected 40 million migrants, says World Bank, Business Today, April 23, 2020, Retrieved from https://www.businesstoday.in/current/econo my-politics/coronavirus-lockdown-in-india-has-affected-40-milli on-migrants-says-world-bank/story/401762.html.

[9] E.G. Carayannis, and D.F.J. Campbell, Mode 3 and Quadruple Helix: Toward a 21st Century Fractal Innovation Ecosystem, Int. J. Technol. Manag., 46(2009) 201-234.

[10] H. Etzkowitz, and L. Leydesdorff, The Triple Helix-University-Industry-Government Relations: A Laboratory for Knowledge-Based Economic Development, EASST Review, 14(1995) $14-19$.
[11] H. Etzkowitz, and L. Leydesdorff, The Dynamics of Innovation: From National Systems and Mode 2 To a Triple Helix of University-Industry-Government Relations, Research Policy, 29(2000) 109-123.

[12] H. Etzkowitz, A. Webster, C. Gebhardt, and B.R.C. Terra, The Future of the University and the University of the Future: Evolution of Ivory Tower to Entrepreneurial Paradigm, Res. Policy, 29(2000) 313-330.

[13] Quality infrastructure, United State of America, Retrieved from https://www.bipm.org/en/about-us/member-states/us/links.html.

[14] Quality Infrastructure: UNIDO's unique approach, 2018, Retrieved from https://www.unido.org/sites/default/files/ files/2018-08/UNIDO_QI_CASE_FINAL_ONLINE_2.pdf.

[15] Quality infrastructure- building trust for trade, The United Nations Industrial Development Organization (UNIDO), 2016, Retrieved from https://www.unido.org/sites/default/files/ 2016-05/UNIDO_Quality_system_0.pdf.

[16] Ulrich Harmes-Liedtke, Juan José Oteiza Di Matteo, Measurement of Quality Infrastructure, published by PhysikalischTechnische Bundesanstalt, Germany, 2011, Retrieved from https://www.ptb.de/cms/fileadmin/internet/fachabteilungen/abtei lung_9/9.3_internationale_zusammenarbeit/q5_publikationen/3 05_Discussion_5_Measurement_QI/PTB_Q5_Discussion5_Mea surement_QI_EN.pdf.

[17] What is metrology? BIPM, Retrieved from https://www. bipm.org/en/worldwide-metrology/.

[18] What is conformity assessment? International organization for standardization, Retrieved from https://www.iso.org/confor mity-assessment.html.

[19] INetQI: International network on Quality Infrastructure, Retrieved from https://www.inetqi.net/.

[20] National Institute of Standard and Technology, US Department of Commerce, Retrieved from https://www.nist.gov/.

[21] National Physical Laboratory, New Delhi, Retrieved from http://www.nplindia.in/.

[22] Bhabha Atomic Research Centre (BARC), Trombay, Mumbai, Retrieved from http://www.barc.gov.in/.

[23] Legal Metrology, Department of Consumers Affairs, New Delhi, Retrieved

from https://consumeraffairs.nic.in/organisation-and-units/division/ legal-metrology/overview.

[24] Quality Council of India, New Delhi, Retrieved from https://www.qcin.org/.

[25] Bureau of Indian Standards, Retrieved from https://bis.gov.in/.

[26] International equivalence of measurements: the CIPM MRA, Retrieved from https://www.bipm.org/en/cipm-mra/.

[27] Asia Pacific Metrology Program, Retrieved from http://www. apmpweb.org/.

[28] Calibration and measurement capabilities (CMCs), International bureau of weights and measures (BIPM), Retrieved from https://www.bipm.org/utils/common/pdf/KCDB/ KCDB_CMCs.pdf.

[29] D.K. Aswal, The SI Redefinition to Come Into Force from 20 May 2019,, Current Science, 113(2017) 2066-2067.

[30] S. Yadav, and D.K. Aswal, Redefined SI Units and Their Implications, MAPAN, 35(2020) 1-9.

[31] International Organization of Legal Metrology (OIML), retrieved from https://www.oiml.org/en.

[32] The legal metrology act, retrieved from https://consume raffairs.nic.in/forms/contentpage. aspx ?lid=639.

[33] Agricultural \& Processed food Products Export Development Authority (APEDA), Retrieved from https://apeda.gov.in/ apedawebsite/.

[34] Automotive Research Association of India (ARAI), Retrieved from https://www.araiindia.com/home. 
[35] Building Materials \& Technology Promotion Council (BMPTC), Retrieved from http://bmtpc.org/.

[36] Bureau of Energy Efficiency (BEE), Retrieved from https://beeindia.gov.in/.

[37] Directorate of Marketing and inspection (DMI), Retrieved from https://dmi.gov.in/.

[38] The Food Safety and Standards Authority of India (FSSAI), Retrieved from https://www.fssai.gov.in/cms/food-safetyand-standards-regulations.php.

[39] Indian Road Congress (IRC), Retrieved from http://www. irc.nic.in/.

[40] Ministry of AYUSH (Ayurveda, Yoga \& naturopathy, Unani, Siddha and Homoeopathy), Retrieved from https://www. ayush.gov.in/.

[41] Standardisation Testing and Quality Certification (STQC), Retrieved from http://www.stqc.gov.in/.

[42] Telecommunication Engineering Centre (TEC), Retrieved from http://www.tec.gov.in/.

[43] Telecommunications Standards Development Society, India (TSDSI), Retrieved from https://tsdsi.in/.

[44] National Accreditation Board for Testing and Calibration Laboratories (NABL), Retrieved from http://www.nabl-india.org/.

[45] International Laboratory Accreditation Co-operation (ILAC), Retrieved from https://ilac.org/.

[46] Asia Pacific Laboratory Accreditation Co-operation (APLAC), Retrieved from https://aplac.org/.

[47] National Accreditation Board for Certification Bodies (NABCB), Retrieved from http://nabcb.qci.org.in/.

[48] National Accreditation Board for Hospitals and Healthcare Providers (NABH), Retrieved from https://www.nabh.co/.

[49] National Accreditation Board for Education \& Training (NABET), Retrieved from http://nabet.qci.org.in/.

[50] Cheap imports and quality-killing cancer, The Statesman, February 2, 2018, Retrieved from https://www.thestatesman. com/opinion/cheap-imports-quality-killing-cancer- 1502577960. html.

[51] India's booming solar sector has one major flaw: poor quality, Quartz India, August 2, 2018, Retrieved from https://qz. com/india/1345508/poor-quality-solar-panels-may-ruin-indiasrenewable-energy-boom/.

[52] Eight Chinese pharma cos to be blacklisted for quality issues, may lead to shortage of medicines, Firstpost, January 8, 2018, Retrieved from https://www.firstpost.com/india/centre-issues- showcause-notices-to-8-chinese-pharmaceutical-companies-forpoor-quality-raw-materials-4291337.html.

[53] Low quality imports harm India's LED market, Lux, August 5 , 2014, Retrieved from http://luxreview.com/article/2014/08/ low-quality-imports-harm-india-s-led-market.

[54] Battery making firms wants government to prevent poor quality imports from China, DNA, February 1, 2016, Retrieved from https://www.dnaindia.com/business/report-battery-making-firms -wants-government-to-prevent-poor-quality-imports-from-china -2172441 .

[55] Chinese imports hurt Eveready, The Telegraph, May 7, 2016, Retrieved from https://www.telegraphindia.com/1160507/jsp/ business/story_84296.jsp.

[56] Why so many Indian food product exports get rejected, Rediff.com, September 13, 2016, Retrieved from http://www. rediff.com/money/report/why-so-many-indian-food-product-ex ports-get-rejected/20160913.htm.

[57] 13,334 'made-in-India' items rejected by US-FDA in 6 yrs, Times of India, February 11, 2016, Retrieved from https://timesofindia.indiatimes.com/india/13334-made-in-Indiaitems-rejected-by-US-FDA-in-6-yrs-1753-less-than-China/arti cleshow/50909128.cms.

[58] Food industry must focus on quality to avoid rejection in export mkt: Govt, India Today, June 19, 2018, Retrieved from https://www.indiatoday.in/pti-feed/story/food-industry-must-foc us-on-quality-to-avoid-rejection-in-export-mkt-govt-12642692018-06-19.

[59] Micro, Small and Medium Enterprises, Retrieved from https://msme.gov.in/.

[60] Make in India, Department of Industrial Policy and Promotion, Retrieved from https://dipp.gov.in/programmes-and-schemes/ industrial-promotion/investment-promotion.

[61] Recommendations of the Inter-Ministerial Committee for Accelerating Manufacturing in Micro, Small \& Medium Enterprises Sector, Retrieved from https://msme.gov.in/sites/ default/files/Accelerating\%20Manufacturing\%20in\%20the $\% 20$ MSME\%20Sector_0.pdf.

[62] About certified reference materials - about COMAR, https://rrr. bam.de/RRR/Navigation/EN/Reference-Materials/COMAR/Co mar-about/comar-about.html.

Publisher's Note Springer Nature remains neutral with regard to jurisdictional claims in published maps and institutional affiliations. 